\title{
Challenges in cancer management during SARS-CoV-2 pandemic: a systematic
}

\section{review}

\author{
Desafios no tratamento do câncer durante a pandemia de SARS-CoV-2: uma revisão sistemática \\ Desafíos en el manejo del cáncer durante la pandemia de SARS-CoV-2: una revisión sistemática
}

Received: 02/24/2021 | Reviewed: 03/03/2021 |Accept: 03/08/2021 | Published: 03/14/2021

\author{
Alan Paulo Amaral Oliveira \\ ORCID: https://orcid.org/0000-0002-1742-9343 \\ Universidade Federal de Alfenas, Brazil \\ E-mail: alan.amara195@outlook.com \\ Alícia Rocha de Mesquita Schafranek \\ ORCID: https://orcid.org/0000-0001-9434-8638 \\ Universidade Federal de Alfenas, Brazil \\ E-mail: schafranek@sou.unifal-mg.edu.br \\ Larissa de Oliveira Briganti Carvalho \\ ORCID: https://orcid.org/0000-0001-7620-5668 \\ Universidade Federal de Alfenas, Brazil \\ E-mail: lah.briganti@gmail.com \\ Mariana Martins de Vitro \\ ORCID: https://orcid.org/0000-0003-0013-655X \\ Universidade Federal de Alfenas, Brazil \\ E-mail: mariana.vitro@sou.unifal-mg.edu.br \\ Renata Messias Frazão \\ ORCID: https://orcid.org/0000-0002-9430-0500 \\ Universidade Federal de Alfenas, Brazil \\ E-mail: renatamfrazao@gmail.com \\ Victor Alves Nascimento \\ ORCID: https://orcid.org/0000-0002-8190-2297 \\ Universidade Federal de Alfenas, Brazil \\ E-mail: victoralves_nascimento@hotmail.com \\ Pollyanna Francielli de Oliveira ${ }^{1}$ \\ ORCID: https://orcid.org/0000-0002-1646-0277 \\ Universidade Federal de Alfenas, Brazil \\ E-mail: pollyanna.oliveira@gmail.com
}

\begin{abstract}
The SARS-CoV-2 spread and the installation of a pandemic generated drastic changes in society's lifestyle, in health practices, and in the way we do and consume science. There are countless uncertainties regarding the virus and its health implications, especially for individuals from vulnerable groups, such as oncologic patients. The aim of this systematic review was to identify what has been the reality of oncology in the SARS-CoV-2 pandemic. A systematic review was carried out on the Pubmed ${ }^{\circledR}$ platform, based on the Prisma protocol, using the following keywords were searched: COVID-19 and Cancer. Among the 94 works selected, including systematic reviews, reviews, randomized trials, multicenter studies, meta-analysis, controlled clinical-trials, comparative studies and case reports, only 36 publications corresponded to the purpose of this study and were used. The results showed that, despite the large volume of studies, there is no consensus concerning gold standard measures. As individuals with cancer tend to evolve with more severe conditions when infected with SARS-CoV-2, oncology services have adopted protocols to guarantee adequate management and prevent the spread of the infection onto its facilities. The possible scarcity of resources during the SARS-CoV-2 pandemic brought the necessity to adapt adjust clinical conduct in oncology. Considering the severity and the possibility of a sudden progression of some types of cancer, the professionals must analyze all cases individually to determine the best approach.
\end{abstract}

Keywords: COVID-19; SARS-CoV-2; Cancer; Oncology; Surgical oncology.

\footnotetext{
${ }^{1}$ Corresponding author: Pollyanna Francielli de Oliveira. Tel.: +55-35-3701-9772.
} 


\begin{abstract}
Resumo
A disseminação do SARS-CoV-2 e a instalação de uma pandemia geraram mudanças drásticas no estilo de vida da sociedade, nas práticas de saúde e na forma como fazemos e consumimos ciência. São inúmeras as incertezas em relação ao vírus e suas implicações para a saúde, principalmente para indivíduos de grupos vulneráveis, como os pacientes oncológicos. O objetivo desta revisão sistemática foi identificar qual tem sido a realidade da oncologia na pandemia do SARS-CoV-2. Foi realizada uma revisão sistemática na plataforma Pubmed®, com base no protocolo Prisma, utilizando os seguintes descritores: COVID-19 e Câncer. Entre os 94 trabalhos selecionados, incluindo revisões sistemáticas, revisões, ensaios randomizados, estudos multicêntricos, metanálises, ensaios clínicos controlados, estudos comparativos e relatos de caso, apenas 36 publicações corresponderam ao objetivo deste estudo e foram utilizadas. Os resultados mostraram que, apesar do grande volume de estudos, não há consenso sobre as medidas padrão-ouro. Como os indivíduos com câncer tendem a evoluir para quadros mais graves quando infectados pelo SARS-CoV-2, os serviços de oncologia têm adotado protocolos para garantir o manejo adequado e prevenir a disseminação da infecção em suas instalações. A possível escassez de recursos durante a pandemia do SARS-CoV-2 trouxe a necessidade de adequar a conduta clínica em oncologia. Considerando a gravidade e a possibilidade de progressão súbita de alguns tipos de câncer, os profissionais devem analisar todos os casos individualmente para determinar a melhor conduta.
\end{abstract}

Palavras-chave: COVID-19; SARS-CoV-2; Câncer; Oncologia; Oncologia cirúrgica.

\title{
Resumen
}

La propagación del SARS-CoV-2 y la instalación de una pandemia generaron cambios drásticos en el estilo de vida de la sociedad, en las prácticas de salud y en la forma en que hacemos y consumimos ciencia. Existen innumerables incertidumbres sobre el virus y sus implicaciones para la salud, especialmente para las personas de grupos vulnerables, como los pacientes oncológicos. El objetivo de esta revisión sistemática fue identificar cuál ha sido la realidad de la oncología en la pandemia del SARS-CoV-2. Se realizó una revisión sistemática en la plataforma Pubmed®, basada en el protocolo Prisma, mediante la búsqueda de las siguientes palabras clave: COVID-19 y Cancer. De los 94 trabajos seleccionados, entre revisiones sistemáticas, revisiones, ensayos aleatorizados, estudios multicéntricos, metaanálisis, ensayos clínicos controlados, estudios comparativos e informes de casos, solo 36 publicaciones correspondieron al propósito de este estudio y fueron utilizadas. Los resultados mostraron que, a pesar del gran volumen de estudios, no existe un consenso sobre las medidas estándar de oro. Dado que las personas con cáncer tienden a evolucionar con condiciones más graves cuando se infectan con SARS-CoV-2, los servicios de oncología han adoptado protocolos para garantizar un manejo adecuado y prevenir la propagación de la infección a sus instalaciones. La posible escasez de recursos durante la pandemia de SARS-CoV-2 trajo la necesidad de adaptar la conducta clínica en oncología. Teniendo en cuenta la gravedad y la posibilidad de una progresión brusca de algunos tipos de cáncer, los profesionales deben analizar todos los casos de forma individual para determinar el mejor abordaje.

Palabras clave: COVID-19; SARS-CoV-2; Cáncer; Oncología; Oncología quirúrgica.

\section{Introduction}

On December 2019, a new variety of coronavirus had surged in Wuhan, China. Since then, it has spread for several countries, leading to thousands of obits and millions of infected humans. This new coronavirus is known as SARS-CoV-2 and on 11th February 2020, the World Health Organization (WHO, 2020) named this disease as Coronavirus Disease 2019 (COVID-19) (Ackermann, et al., 2020). The COVID-19 has emerged as the pandemic of the century, leading to a global concern (Cucinotta \& Vanelli, 2020). Fever, cough, fatigue and gastrointestinal symptoms are the main clinical presentations. But, some patients could develop acute respiratory distress syndrome, respiratory failure, multiple organ failure and, therefore, death (Guo, et al., 2020). Other presentations as olfactory and gustatory disfunctions are also described (Pimentel, 2020). Computed tomographic (CT) may reveal peripheral lung ground-glass opacities in COVID-19 patients (Ackermann, et al., 2020). There are some risk factors related to COVID-19, like as age >65 years, cardiovascular disease, chronic lung disease, hypertension, diabetes, obesity and some diseases, like cancer, has an unclear association with complications (Gandhi, et al., 2020). However, an elevated case fatality rate (5,6\% vs. $2,3 \%)$ and a more complicated clinical presentation it has been noticed in these patients, especially in elderly cancer patients (Zhang, et al., 2020a; Silva Filho, et al., 2020). In this sense, the management of cancer patients is a challenge for health workers, especially in decisions involving resource allocation, diagnosis, hospitalization, surgical procedures and anticancer therapy maintenance (Al-Shamsi, et al., 2020). Therefore, the 
aim of this systematic review was identifying the main changes and challenges in the management of oncologic patients during the SARS-CoV-2 pandemic.

\section{Methodology}

In the development of this systematic review, made based on the Prisma protocol (Moher, et al., 2015), the data collection technique utilized was the analysis of documents and publications present in official acquis and databases (Pereira et al., 2018). On the Pubmed® platform, COVID-19 and Cancer were the keywords searched, which led to 899 publications until 17th May 2020. For this study, systematic reviews, reviews, randomized controlled trials, multicenter studies, meta-analyses, controlled clinical trials, comparative studies, and case reports were the selected filters. Initially, we obtained 95 publications and, with the reference manager Mendeley ${ }^{\circledR}$, the duplication of an article was verified and deleted. Then, the number of essays turned to about 39 to maintain the two specific search criteria: to identify the real impact of the pandemic on the management and follow-up of cancer patients considering consultations, surgical procedures, chemotherapy, and radiotherapy and clinical trials involving such patients and the search for better approaches. During this full review, 3 of the selected articles were incompatible with the objectives, presenting the main focus on the pathophysiology of COVID-19 or only relating the disease to others, resulting in 36 research used for this purpose (Figure 1).

Figure 1. Literature screening flow chart.

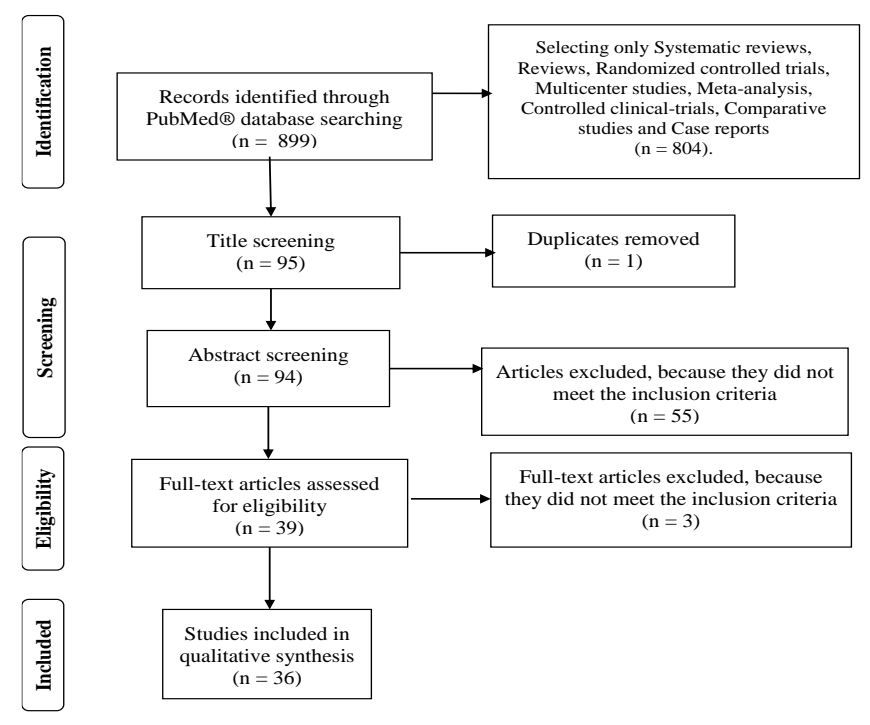

Source: Authors (2021).

\section{Results and Discussion}

After the verification of the selected studies, we found that most of the papers address the virus and its relationship with hematological tumors, lung cancer and surgical procedures in different types of tumors. Some of the studies also discuss measures to combat COVID-19, in addition to general guidelines on the management of cancer patients in this scenario. For this reason, these aspects are recommended to be presented and discussed in this review. In order to better discuss and expose the results of these studies, we presented a compilation of the subjects and main conclusions addressed in the context of the challenges in cancer treatment during the SARS-CoV-2 pandemic (Tables 1, 2, 3, 4 and 5).

In this work, we have established a correlation between the tables and the discussion topics. Table 1 concerns the 
relationship between Cancer and COVID-19, emphasizing aspects linked to the clinical presentation, susceptibility, and diagnosis. Table 2 brings instructions to the hospital team and possible intervention strategies as it discusses the general management of cancer during the SARS-CoV-2 pandemic. Table 3, in turn, presents recommendations about surgical treatment of cancer patients, considering the context of the pandemic and different types of tumors. Finally, tables 4 and 5 provide information on the management of pulmonary and hematological tumors, offering management suggestions for these tumor types. We chose to treat these two tumor types separately in this study as they were the subject of discussion in a considerable number of studies. 
Table 1. Cancer and COVID-19: clinical presentation, susceptibility and diagnosis.

\begin{tabular}{|c|c|c|c|}
\hline $\begin{array}{l}\text { Reference } \\
\text { (Country) }\end{array}$ & Avaliated group & Type of study and its considerations & Main Conclusions \\
\hline $\begin{array}{l}\text { Albano et al., } \\
2020 \text { (Italy). }\end{array}$ & $\begin{array}{l}\text { Asymptomatic patients } \\
\text { who underwent PET / } \\
\text { CT exams with } 18 \mathrm{~F}- \\
\text { FDG for oncological } \\
\text { purposes. }\end{array}$ & $\begin{array}{l}\text { A Case series that analyzed hybrid imaging } \\
\text { studies of asymptomatic patients who } \\
\text { underwent 18F-FDG PET/CT or 131I } \\
\text { SPECT/CT for standard oncologic } \\
\text { indications and was found images } \\
\text { suggestive of COVID-19. }\end{array}$ & $\begin{array}{l}\text { Incidental findings suggestive of COVID- } 19 \text { may be common in the hybrid image of } \\
\text { asymptomatic patients. It is not proven that nuclear medicine procedures may have a } \\
\text { role in the primary diagnosis of COVID-19, however when asymptomatic patients are } \\
\text { subjected to tests for other purposes, there may present incidental detection. }\end{array}$ \\
\hline $\begin{array}{lr}\text { Dariya } & \& \\
\text { Nagaraju, } & 2020 \\
\text { (India } & \text { and } \\
\text { USA). }\end{array}$ & $\begin{array}{l}\text { Comorbid population } \\
\text { (patients with cancer, } \\
\text { diabetes, } \\
\text { cardiovascular disease) } \\
\text { with COVID-19. }\end{array}$ & $\begin{array}{l}\text { A Review about the effect of COVID-19 on } \\
\text { cancer patients and patients with other } \\
\text { diseases. }\end{array}$ & $\begin{array}{l}\text { Cancer patients present a greater risk of hospitalization ( } 4 \text { times) and death ( } 10 \text { times). } \\
\text { Avoiding the use or using low doses of immunosuppressive drugs for patients with } \\
\text { cancer and COVID-19. The most of patients with COVID-19 and malignancies had } \\
\text { stage IV cancer with complications. Decreased lung volume and pneumonia have been } \\
\text { seen in patients with lung cancer. }\end{array}$ \\
\hline $\begin{array}{l}\text { Gosain et al., } \\
2020 \text { (USA). }\end{array}$ & $\begin{array}{l}\text { COVID-19 patients, } \\
\text { focusing on cancer } \\
\text { patients due to } \\
\text { immunological status. }\end{array}$ & $\begin{array}{l}\text { A Comprehensive Review that establish } \\
\text { definitions of priority levels to management } \\
\text { of cancer patients to avoid risk. }\end{array}$ & $\begin{array}{l}\text { The intervention recommended: priority A - patients with unstable and high-mortality } \\
\text { rate tumors, B - patients with noncritical condition, permitting 6-8 weeks delay and C } \\
\text { - patients stable condition (delayed for the duration of the COVID-19 pandemic). }\end{array}$ \\
\hline $\begin{array}{l}\text { Minotti et al., } \\
2020 \text { (Italy). }\end{array}$ & $\begin{array}{l}\text { Immunosuppressed } \\
\text { patients, including } \\
\text { cancer patients. }\end{array}$ & $\begin{array}{l}\text { A Systematic Review assessing the } \\
\text { consequences of SARS-CoV-2 infection in } \\
\text { immunosuppressed adults and children. }\end{array}$ & $\begin{array}{l}\text { Cancer was more often associated with a more severe course, but not with a bad } \\
\text { prognosis. Cancer treatments that can change the course of the disease, such as } \\
\text { transplantation and chemotherapy, must not be discontinued or postponed due to the } \\
\text { COVID-19 pandemic. }\end{array}$ \\
\hline $\begin{array}{l}\text { Ky \& Mann, } \\
2020 \text { (EUA). }\end{array}$ & $\begin{array}{l}\text { Patients } \\
\text { underlying with } \\
\text { cardiovascular risk } \\
\text { factors, cardiovascular } \\
\text { disease or cancer. }\end{array}$ & $\begin{array}{l}\text { A review that provide a knowledge base on } \\
\text { clinical trials for cardiovascular physicians } \\
\text { or those involved in cardio-oncology so that } \\
\text { they can better understand how the area } \\
\text { relates to the COVID- } 19 \text { pandemic. }\end{array}$ & $\begin{array}{l}\text { The possibility of SARS-CoV-2 infection in cancer patients is approximately } 2.31 \\
\text { times greater. The average age of infected cancer patients is } 66 \text { years and the } \\
\text { prevalence is } 58.3 \% \text { of non-small cell lung cancer. Cancer patients who contract } \\
\text { COVID-19 have a higher risk (evolve } 39 \% \text { more rapidly versus } 8 \% \text { in patients without } \\
\text { cancer). }\end{array}$ \\
\hline $\begin{array}{l}\text { Spezzani et al., } \\
2020 \text { (Italy). }\end{array}$ & $\begin{array}{l}\text { Immunocompromised } \\
\text { cancer patient } \\
\text { compared to previously } \\
\text { healthy man. }\end{array}$ & $\begin{array}{l}\text { A Case Report. Both patients received } 3 \\
\text { antibiotics }+22^{-} \text {antiviral }+ \\
\text { hydroxychloroquine. }\end{array}$ & $\begin{array}{l}\text { The case of } 2 \text { married patients who contracted the virus, but suffered different } \\
\text { consequences of the disease. Patient } 1 \text { : Female, } 60 \text { years old, she had breast cancer. } \\
\text { Stable patient and no ICU needed. Patient } 2 \text { : husband of patient } 1,60 \text { years old, } \\
\text { history of arterial hypertension, controlled with medication. Transferred to the ICU. } \\
\text { The role of Losartan and Hydrochlorothiazide, used to treat patient } 2 \text {, must be }\end{array}$ \\
\hline
\end{tabular}




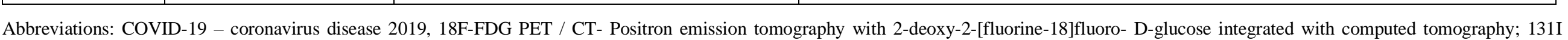
SPECT/CT - 131I single photon emission tomography - computed tomography; SARS-CoV-2 - severe acute respiratory syndrome coronavirus 2 ; ICU - intensive care unit.

Source: Authors (2021).

Table 2. Clinical Management: general strategies to manage cancer in the era of SARS-CoV-2.

\begin{tabular}{|c|c|c|c|}
\hline $\begin{array}{l}\text { Reference } \\
\text { (Country) }\end{array}$ & Avaliated group & Type of study and its considerations & Main Conclusions \\
\hline $\begin{array}{l}\text { Combs et al., } \\
2020 \\
\text { (Germany). }\end{array}$ & Radiotherapy patients. & $\begin{array}{l}\text { A review that offer effective measures to } \\
\text { address COVID-19 in Oncology } \\
\text { Departments. }\end{array}$ & $\begin{array}{l}\text { The treatment with radiation should be fractioned and adapted during pandemic, } \\
\text { according to various types of cancer. }\end{array}$ \\
\hline $\begin{array}{l}\text { Nannan et al., } \\
2020 \text { (China). }\end{array}$ & $\begin{array}{l}\text { Cancer patients with } \\
\text { coronavirus. }\end{array}$ & $\begin{array}{l}\text { A Review analyzing the clinical } \\
\text { characteristics of cancer patients with } \\
\text { coronavirus and offering suggestions for } \\
\text { coping with this new outbreak. }\end{array}$ & $\begin{array}{l}\text { The patient with a tumor is more likely to be infected due to low immune function and } \\
\text { the suppression of the immune system caused by antineoplastic treatments, worse } \\
\text { prognosis and greater propensity for respiratory problems. Symptoms such as fever, } \\
\text { dry cough, myalgia and fatigue are similar in patients without a tumor. However, } \\
\text { imaging findings in tumor patients are more serious and a worse prognosis. The } \\
\text { serological examination corresponding to the infection is necessary. Patients who } \\
\text { have stable tumors and receive radiotherapy and adjuvant chemotherapy, if necessary, } \\
\text { can relax the conditions of application of targeted drugs. The treatment of cancer } \\
\text { patients with COVID-19, the following must be included: strengthening of clinical } \\
\text { monitoring; symptomatic treatment; treatment of basic diseases, prevent } \\
\text { complications; prevent secondary infections; strengthening psychological counseling } \\
\text { for patients, among others. Avoid the inappropriate use of antibacterial drugs (mainly } \\
\text { broad-spectrum)and consider the timely psychological counseling. }\end{array}$ \\
\hline $\begin{array}{l}\text { Moujaess et } \\
\text { al.,2020 } \\
\text { (Lebanon). }\end{array}$ & $\begin{array}{l}\text { Adult cancer patients } \\
\text { with COVID- } 19 \text {. }\end{array}$ & $\begin{array}{l}\text { A Systematic Review that establish } \\
\text { strategies to achieve proper management of } \\
\text { cancer in the era of SARS-CoV-2. }\end{array}$ & $\begin{array}{l}\text { The care offered to oncologic patients must be dynamic and customized, according to } \\
\text { each patient's need and condition, medical resources, and oncologist's } \\
\text { knowledge/opinion. It is important to notice the fact that, if COVID-19 pandemic } \\
\text { extends, the shortage of oncologic targeted follow-up and treatment will be more life- } \\
\text { threatening than SARS-CoV-2 infection. }\end{array}$ \\
\hline $\begin{array}{l}\text { Ierardi et al., } \\
2020 \text { (Italy). }\end{array}$ & $\begin{array}{l}\text { Medical team and } \\
\text { patients in a region with } \\
\text { a high incidence and }\end{array}$ & $\begin{array}{l}\text { A Review about control measures to } \\
\text { decrease the rate of intra-institutional spread } \\
\text { of SARS-CoV-2. }\end{array}$ & $\begin{array}{l}\text { No incident was documented at pre-, intra- and post-procedure approaches during the } \\
\text { workflow in interventional radiology. The current world scenario, due to the rapid } \\
\text { spread of COVID-19, requires drastic preventive measures from all areas of medicine }\end{array}$ \\
\hline
\end{tabular}




\begin{tabular}{|c|c|c|c|}
\hline & prevalence. & & to efficiently combat the pandemic. \\
\hline $\begin{array}{l}\text { Wei et al., } \\
2020 \text { (China). }\end{array}$ & $\begin{array}{l}\text { Cancer patients at } \\
\text { Hubei Cancer Hospital } \\
\text { in Wuhan, China. }\end{array}$ & $\begin{array}{l}\text { A Review that offer instructions to the } \\
\text { hospital team in the hospital's oncoradiology } \\
\text { sector. }\end{array}$ & $\begin{array}{l}\text { The authors suggest zoning at different levels of protection and prevention, } \\
\text { organization, training and rotation of teams, instruction of patients, rigorous } \\
\text { disinfection procedures and creation of preparatory plans for possible emergencies. } \\
\text { During the time the study was conducted ( } 6 \text { weeks) no new infections were observed. }\end{array}$ \\
\hline $\begin{array}{l}\text { von Lilienfeld- } \\
\text { toal et al., } \\
2020 \\
\text { (Germany, } \\
\text { Italy, } \\
\text { Switzerland, } \\
\text { UK, Turkey, } \\
\text { Belgium, } \\
\text { Austria, } \\
\text { Russia, The } \\
\text { Netherlands, } \\
\text { France and } \\
\text { Czech Republic). } \\
\text { Repu }\end{array}$ & $\begin{array}{l}\text { Patients with active and } \\
\text { with controlled } \\
\text { malignant disease. }\end{array}$ & $\begin{array}{l}\text { A Review of cancer patient management } \\
\text { during outbreak. }\end{array}$ & $\begin{array}{l}\text { Patient with active malignant disease without RTID symptoms: if the risk for SARS- } \\
\text { CoV-2 infection is low, no therapy should be postponed. If the risk is high, contact } \\
\text { isolation measures are essential, and mild immunosuppressive therapies should be } \\
\text { chosen. Patient with active malignant disease with RTID symptoms: if the symptoms } \\
\text { are mild, the patient should be tested for infections including SARS-CoV-2 and re- } \\
\text { evaluated after one week. If the patient's condition improved, the cancer therapy shall } \\
\text { proceed. If the symptoms are severe or the patient has LRTID, the case must be } \\
\text { analyzed individually. Patient with controlled malignant disease without RTID } \\
\text { symptoms: if the risk for SARS-CoV-2 infection is low, no therapy should be } \\
\text { postponed. If the risk is high, contact isolation measures are essential, but no therapy } \\
\text { should be interrupted. Patient with active malignant disease with RTID symptoms: if } \\
\text { the therapy in use is intermittent, deferral is recommended until symptoms disappear } \\
\text { and if the therapy is continuous, the case must be analyzed individually. }\end{array}$ \\
\hline $\begin{array}{l}\text { Weisel et al ., } \\
2020 \\
\text { (Germany). }\end{array}$ & $\begin{array}{l}\text { Cancer patients in } \\
\text { clinical care. }\end{array}$ & $\begin{array}{l}\text { A Review that describes the measures taken } \\
\text { by the University Cancer Center Hamburg } \\
\text { during outbreak. }\end{array}$ & $\begin{array}{l}\text { Problems with the availability of resources and employees and the change in social } \\
\text { behavior will have a negative impact on cancer diagnoses, which have already been } \\
\text { observed to be reduced, and which will be made when the cases are already in more } \\
\text { advanced stages. For the management of this crisis, measures were adopted such as } \\
\text { the establishment of a task force for making decisions about safety, treatment, care } \\
\text { conducts, use of resources and suspension of outpatient visits that have either been } \\
\text { replaced by virtual. Some treatments were postponed, giving preference to those with } \\
\text { curative. }\end{array}$ \\
\hline
\end{tabular}




\begin{tabular}{|c|c|c|c|}
\hline $\begin{array}{l}\text { van de Haar et } \\
\text { al., } 2020 \\
\text { (Netherlands, } \\
\text { UK, Germany, } \\
\text { Italy, Sweden, } \\
\text { France and } \\
\text { Spain). }\end{array}$ & $\begin{array}{l}\text { The management of } \\
\text { cancer patients by } \\
\text { health professionals. }\end{array}$ & $\begin{array}{l}\text { A Review of European Guidelines about } \\
\text { cancer care during the COVID-19 pandemic. }\end{array}$ & $\begin{array}{l}\text { Report on how } 7 \text { European health centers organized their health system to face the } \\
\text { pandemic. What is being prioritized is to leave these centers free of COVID-19, so } \\
\text { that all cancer patients have their surgeries maintained and the continuation of } \\
\text { treatment. Most consultations are made online or over the phone. For face-to-face } \\
\text { treatment, the patient cannot be accompanied. Patients demand for mental health } \\
\text { information and assistance has also grown a lot. To this end, an online chat room was } \\
\text { created with updated question and answer sections on COVID-19. }\end{array}$ \\
\hline
\end{tabular}

Abbreviations: SARS-CoV-2 - severe acute respiratory syndrome coronavirus 2; COVID-19 - coronavirus disease 2019; LRTID - Lower respiratory tract infection disease; RTID - respiratory tract infection disease. Source: Authors (2021)

Table 3. Surgery in Oncology: postpone or not postpone?

\begin{tabular}{|c|c|c|c|}
\hline $\begin{array}{l}\text { Reference } \\
\text { (Country) }\end{array}$ & Avaliated group & Type of study and its considerations & Main Conclusions \\
\hline $\begin{array}{l}\text { Kimmig et al., } \\
2020 \text { (Germany, } \\
\text { Netherlands and } \\
\text { Denmark). }\end{array}$ & $\begin{array}{l}\text { Patients who require } \\
\text { laparoscopic surgery } \\
\text { with the use of RAS, } \\
\text { especially r for } \\
\text { gynecological cancer. }\end{array}$ & $\begin{array}{l}\text { A review that verifies implications over } \\
\text { robot-assisted surgery (RAS) during the } \\
\text { pandemic in patients that urgently need } \\
\text { complex-oncological-surgery, including } \\
\text { COVID-19 patients. }\end{array}$ & $\begin{array}{l}\text { The surgeries must be considered high risk, regardless of the patients' status in relation } \\
\text { to COVID-19, and with each operation, strict preventive measures must be } \\
\text { implemented. Robot assisted surgery (RAS) is able to reduce contamination by body } \\
\text { fluids and surgical phases in the surgical area, in addition to decreasing the number of } \\
\text { medical staff that would be directly exposed. In operations with RAS the assistant has } \\
\text { level III protection and the console surgeon uses level II protection, equivalent to the } \\
\text { protection recommended for those working in an isolation ward area. Nursing rounds } \\
\text { and outpatient care should not be in the routine of the surgical team at this time. If } \\
\text { these strict precautions cannot be followed and taken (for example, due to lack of } \\
\text { equipment), it should be assessed whether open surgery should be considered the } \\
\text { safest or whether the surgery would in fact be viable in all circumstances. }\end{array}$ \\
\hline $\begin{array}{l}\text { Shinde et al., } \\
2020 \text { (India). }\end{array}$ & $\begin{array}{llr}\text { Patients } & \text { who } & \text { will } \\
\text { undergo } & \text { a } & \text { cancer } \\
\text { surgery. } & & \end{array}$ & $\begin{array}{l}\text { Review of triage guidelines for cancer } \\
\text { surgery in pandemic times by COVID- } 19 .\end{array}$ & $\begin{array}{l}\text { The postponement of oncological surgery will depend on the availability of blood and } \\
\text { blood products, because with the existing cases of COVID-19, it is possible to have } \\
\text { fewer volunteers for donating sengue due to the history of exposure, symptoms and } \\
\text { positivity for SARS-CoV-2. The increase in the extent of surgery, perioperative } \\
\text { mobimortality and, in the waiting time for surgery, may reduce the index of cure. } \\
\text { Regional anesthesia should be preferred for use whenever possible, due to less effect } \\
\text { on lung function compared to general anesthesia. In advanced gastrointestinal cancers, } \\
\text { neoadjuvant therapy should be offered whenever possible. If adequate facilities are }\end{array}$ \\
\hline
\end{tabular}




\begin{tabular}{|c|c|c|c|}
\hline & & & $\begin{array}{l}\text { available for transcatheter arterial embolization, this procedure should be made an } \\
\text { option for hemorrhagic tumors. When mandatory postoperative assisted mechanical } \\
\text { ventilation procedures, elective tracheostomy and extensive reconstructions are } \\
\text { required due to elective airway surgery, they should preferably be postponed. Surgery } \\
\text { for prostate cancer and most kidney cancers can be safely postponed for a few days } \\
\text { due to the slow doubling time of these types of cancers. Postponement of breast } \\
\text { cancer surgery can be done when for early lesions and suspected benign pathology, } \\
\text { and two to three weeks can be expected for those who have completed neoadjuvant } \\
\text { therapy. If surgery for an endocrine tumor is not an imminent threat to the airways, } \\
\text { pheochromocytoma and functional neuroendocrine tumors refractory to medical } \\
\text { treatment, most may be delayed. Otherwise, no. }\end{array}$ \\
\hline $\begin{array}{l}\text { Deo et al., } 2020 \\
\text { (India). }\end{array}$ & $\begin{array}{l}\text { Surgical } \\
\text { patients. }\end{array}$ & $\begin{array}{l}\text { A case report with recommendations about } \\
\text { the surgical treatment of cancer patients, } \\
\text { considering the context of the pandemic. }\end{array}$ & $\begin{array}{l}\text { Surgeons are confronted by complicated ethical and moral dilemmas because most } \\
\text { cancer surgeries are elective but cannot be postponed due to the evolution of the } \\
\text { disease and the chances of survival. Assess the pandemic status in the region, the } \\
\text { availability of resources and the condition of the patient and his tumor are the basis for } \\
\text { decision making. It is also recommended to involve the family and the patient in the } \\
\text { conscious decision about the treatment plan. In cases of emergency oncological } \\
\text { surgeries, the protection protocols stipulated and for elective oncology surgeries, the } \\
\text { decision must be individualized and based on the type, stage and biology of the tumor, } \\
\text { as well as the availability of material and non-material resources must be considered. } \\
\text { Elective surgeries for less aggressive and slowly growing cancers should be } \\
\text { postponed. }\end{array}$ \\
\hline $\begin{array}{l}\text { Puliatti et al., } \\
2020 \text { (Italy). }\end{array}$ & $\begin{array}{l}\text { Urological and uro- } \\
\text { oncological patients. }\end{array}$ & $\begin{array}{l}\text { A comprehensive review, enlightening } \\
\text { about the best approaches to urological } \\
\text { cancer patients during the pandemic. }\end{array}$ & $\begin{array}{l}\text { Urological cancer surgeries were divided into four categories: non-deferrable, include } \\
\text { all the procedures whose delay may negatively affect the oncological or functional } \\
\text { outcomes; semi-non-deferrable, depending on the prevalence of COVID-19 in the } \\
\text { region; deferrable; and replaceable with other treatments. An important caveat is that } \\
\text { restricting cancer surgeries to emergencies can harm patients with time-sensitive } \\
\text { prognosis. }\end{array}$ \\
\hline $\begin{array}{l}\text { Ye et al, } 2020 \\
\text { (China). }\end{array}$ & $\begin{array}{l}\text { Colon cancer patient } \\
\text { infected with COVID- } \\
19 .\end{array}$ & $\begin{array}{l}\text { A case report discusses the feasibility of } \\
\text { surgical treatment for cancer patients and } \\
\text { COVID-19. }\end{array}$ & $\begin{array}{l}\text { There is the possibility of submitting a patient with cancer and COVID-19, } \\
\text { concomitantly, to radical surgical treatment to remove the tumor. However, treatment } \\
\text { is indicated after the virus nucleic acid testing turns negative. }\end{array}$ \\
\hline $\begin{array}{l}\text { Tchelebi et al., } \\
2020 \text { (EUA). }\end{array}$ & $\begin{array}{l}\text { Gastrointestinal cancer } \\
\text { patients }\end{array}$ & $\begin{array}{l}\text { A review that suggests how to manage } \\
\text { chemotherapy (CT), chemo-radiation } \\
\text { therapy (CRT), and surgery in patients with }\end{array}$ & $\begin{array}{l}\text { For operable esophageal cancer concurrent CRT is recommended, for operable gastric } \\
\text { cancer the peri-op chemotherapy is recommended, and for cholangiocarcinoma and } \\
\text { rectal cancer, induction chemotherapy is recommended. Surgery must be performed in }\end{array}$ \\
\hline
\end{tabular}




\begin{tabular}{|c|c|c|c|}
\hline & & different cancer stages during the pandemic. & $\begin{array}{l}\text { the last three mentioned, but rectal cancer patients must receive RT before surgery. } \\
\text { Resectable and borderline resectable pancreas cancer patients might receive } \\
\text { neoadjuvant chemotherapy and proceed to surgery. For inoperable esophageal cancer } \\
\text { definitive CRT is recommended, for inoperable cholangiocarcinoma and rectal cancer } \\
\text { the induction chemotherapy is recommended, proceeded by RT. Inoperable pancreas } \\
\text { cancer patients must receive only chemotherapy. Palliative RT is recommended for } \\
\text { advanced stage esophageal and gastric cancer patients. For resected gastric cancer } \\
\text { patients, chemotherapy only is recommended. For hepatocellular carcinoma patients, } \\
\text { the recommended therapy is TACE/Y90 or SBRT. For liver metastatic cancer } \\
\text { patients, chemotherapy is recommended, followed by resection or RFA or SBRT. } \\
\text { Lastly, for anal cancer patients, RT and concurrent chemotherapy is recommended. }\end{array}$ \\
\hline $\begin{array}{l}\text { Glehen et al., } \\
2020 \text { (France). }\end{array}$ & $\begin{array}{l}\text { Patients with peritoneal } \\
\text { tumors. }\end{array}$ & $\begin{array}{l}\text { A review that reinforces the necessity of } \\
\text { demand organization for peritoneal tumor } \\
\text { treatment procedures, allowing equitable } \\
\text { public service during the pandemic. }\end{array}$ & $\begin{array}{l}\text { The management of peritoneal cancers in the pandemic has hindered the treatment and } \\
\text { prognosis of these patients. The continuity and equity of care of these patients is } \\
\text { charged, who have the same rights as patients with COVID-19. The approach of } \\
\text { prioritizing chemotherapy instead of surgery or abstaining from treatment in relation } \\
\text { to the lower risks of COVID-19 contraction is subjective and should be thought of in a } \\
\text { multidisciplinary way. }\end{array}$ \\
\hline $\begin{array}{l}\text { Huang et al., } \\
2020 \text { (China). }\end{array}$ & $\begin{array}{l}\text { COVID-19 positive } \\
\text { patient with acute } \\
\text { gastrointestinal } \\
\text { obstruction. }\end{array}$ & $\begin{array}{l}\text { A case report portrays open sigmoid colonic } \\
\text { resection and its implications during the } \\
\text { pandemic. }\end{array}$ & $\begin{array}{l}\text { There is still no way to affirm the efficacy of perioperative risk stratification applied } \\
\text { to infected patients. As fecal Sars-CoV-2 RNA was detected and all the operative } \\
\text { tissue and refuse removed in the bowel surgeries will probably contain fecal } \\
\text { contamination, they must be considered as a potential SARS-CoV-2 infection source } \\
\text { and receive proper treatment. }\end{array}$ \\
\hline $\begin{array}{l}\text { Pawar et al., } \\
2020 \text { (India). }\end{array}$ & $\begin{array}{l}\text { Patient with carcinoma } \\
\text { rectum. }\end{array}$ & $\begin{array}{l}\text { A case report portrays laparoscopic anterior } \\
\text { resection and its implications during the } \\
\text { pandemic. }\end{array}$ & $\begin{array}{l}\text { There was no validation based on scientific evidence that exists a potential chance of } \\
\text { contamination by SARS-CoV-2 during a laparoscopy procedure. However, due to the } \\
\text { high infectivity of the virus, necessary precautions must always be taken to minimize } \\
\text { the risks. }\end{array}$ \\
\hline $\begin{array}{l}\text { Weller } \quad \& \\
\text { Preusser, 2020 } \\
\text { (Switzerland } \\
\text { and Austria). }\end{array}$ & $\begin{array}{l}\text { Patients with brain } \\
\text { tumour }\end{array}$ & $\begin{array}{l}\text { A review that considers ultimate } \\
\text { recommendations over brain tumors } \\
\text { treatments during the COVID- } 19 \text { pandemic. }\end{array}$ & $\begin{array}{l}\text { There is a need to pay attention to the effects of replacing face-to-face consultations } \\
\text { for teleconferences and videoconferences and social isolation on these patients, who } \\
\text { tend to be susceptible to declining cognitive function and the idea that they will soon } \\
\text { die. A beneficial effect of the situation established by the pandemic is the intensified } \\
\text { attention to the execution of a series of questionable interventions that can be harmful } \\
\text { to the patient as operations for tumors that cannot be controlled surgically. The fact is } \\
\text { that the notions of risk and benefit have changed. Clinical trials were particularly } \\
\text { hampered by the pandemic. Most are being conducted in a very cautious manner and }\end{array}$ \\
\hline
\end{tabular}




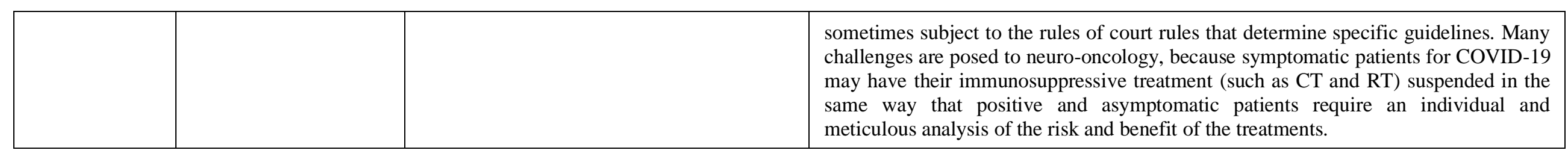

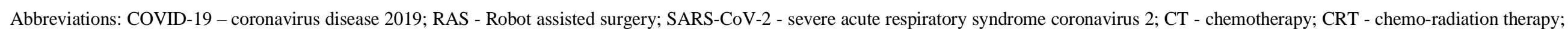
RT- radiotherapy, TACE/Y90 - transarterial chemoembolization/yttrium-90; SBRT - Stereotactic Body Radiotherapy; RFA - Radiofrequency ablation; RNA - Ribonucleic acid.

Source: Authors (2021)

Table 4. Best management and approaches in lung cancer.

\begin{tabular}{|c|c|c|c|}
\hline $\begin{array}{l}\text { Reference } \\
\text { (Country) }\end{array}$ & Avaliated group & $\begin{array}{c}\text { Type } \\
\text { of study and its considerations }\end{array}$ & Main Conclusions \\
\hline $\begin{array}{l}\text { Banna et al., } \\
2020 \text { (Italy and } \\
\text { Switzerland). }\end{array}$ & Lung cancer patients. & $\begin{array}{l}\text { A review that brings practical suggestions to } \\
\text { treat patients with lung cancer during the } \\
\text { SARS-CoV-2 pandemic. }\end{array}$ & $\begin{array}{l}\text { It's necessary to analyse the risk:benefit ratio of systemic anticancer treatment. The } \\
\text { risk can be affected by the age and comorbidities and by the frequency of visits to } \\
\text { hospital to receive treatment. If the regimens have a survival advantage, it should be } \\
\text { sustained and prioritized whenever feasible. Adjuvant treatment may be suspended in } \\
\text { case the survival increasing is discreet and after an attentive discussion with the } \\
\text { patient. On the other hand, Neoadjuvant chemotherapy can become a reasonable } \\
\text { option to postpone the time for surgery, if these services are suspended. Patients who } \\
\text { have contactants (family members or caregivers) whose SARS-CoV- } 2 \text { tests were } \\
\text { positive should also be tested previously or at the time of any cancer treatment. }\end{array}$ \\
\hline $\begin{array}{l}\text { Tian et al., } \\
2020 \text { (China). }\end{array}$ & $\begin{array}{l}\text { Two patients with lung } \\
\text { cancer and probable } \\
\text { changes in the initial } \\
\text { phase of pulmonary } \\
\text { pathology due to } \\
\text { pneumonia by COVID- } \\
19 .\end{array}$ & $\begin{array}{l}\text { A case report in which cases may provide } \\
\text { valuable pieces of information on } \\
\text { pathological studies of COVID-19. }\end{array}$ & $\begin{array}{l}\text { Among the differential diagnoses of COVID-19 pneumonia are, not exclusively, acute } \\
\text { or chronic pneumonia, both from other infections. To discard these hypotheses, } \\
\text { clinical analyzes of epidemiological status, computed tomography and nucleic acid } \\
\text { testing should be performed. It is believed that the time for COVID-19 initial lung } \\
\text { injuries to worsen and clinical symptoms is relatively long. However, radiographic } \\
\text { changes can be detected early (computed tomography) and, therefore, it is } \\
\text { advantageous to make an assessment of the lungs in search of any infiltration, in } \\
\text { addition to performing the serological test. }\end{array}$ \\
\hline $\begin{array}{l}\text { Zhang et al., } \\
2020 \text { (China). }\end{array}$ & $\begin{array}{l}\text { A patient with } \\
\text { advanced lung cancer } \\
\text { and } \\
\text { positive }\end{array}$ & $\begin{array}{l}\text { A case report that considers the results of } \\
\text { treatment with Cefoselis, oseltamivir, } \\
\text { meropenem, teicoplanin, moxifloxacin, and } \\
\text { Kaletra (lopinavir/ritonavir). }\end{array}$ & $\begin{array}{l}\text { CT was perfomed to evaluate not only the COVID- } 19 \text { progression, but also to observe } \\
\text { the cancer condition at the time. The observations were essential to decide if the } \\
\text { monotherapy should be maintained or not. So, osimertinib treatment wasn't } \\
\text { discontinued during COVID-19 diagnose and treatment. }\end{array}$ \\
\hline
\end{tabular}




\begin{tabular}{|c|c|c|c|}
\hline $\begin{array}{l}\text { de la Viña et } \\
\text { al., } \\
\text { (Spain). }\end{array}$ & $\begin{array}{l}\text { Lung cancer patients } \\
\text { on the waiting list for } \\
\text { surgery. }\end{array}$ & $\begin{array}{l}\text { A case report that brings COVID- } 19 \\
\text { guidelines for triage of thoracic surgery of } \\
\text { cancer patients. }\end{array}$ & $\begin{array}{l}\text { The guidelines of the American College of Surgeons talks about providing a non- } \\
\text { surgical alternative to patients with lung cancer, as an optional treatment. The } \\
\text { Oncological Surgery Society, on the other hand, discusses other guidelines to be } \\
\text { considered for patients, which is for doctors to take into account the scarcity of } \\
\text { resources and beds, which are all deviated to the treatment of COVID-19. Among } \\
\text { patients who have cancer and tested positive for COVID-19, 25\% suffered from lung } \\
\text { cancer, presenting symptoms such as dyspnea, elevated C-reactive protein and } \\
\text { hypoproteinemia, these symptoms would prevent surgery on patients on the waiting } \\
\text { list. Surgery is the most recommended therapy, since treatments that can cause } \\
\text { immunosuppression. All patients must be treat within } 3 \text { months according to the stage } \\
\text { and location of the cancer. }\end{array}$ \\
\hline
\end{tabular}

Abbreviations: COVID-19 - coronavirus disease 2019; SARS-CoV-2 - severe acute respiratory syndrome coronavirus 2; CT - computed tomography

Source: Authors (2021)

Table 5. Best management and approaches in hematological tumors.

\begin{tabular}{|c|c|c|c|}
\hline $\begin{array}{l}\text { Reference } \\
\text { (Country) }\end{array}$ & Avaliated group & Type of study and its considerations & Main Conclusions \\
\hline $\begin{array}{l}\text { Mahmoudjafari } \\
\text { et al., } 2020 \\
\text { (EUA). }\end{array}$ & $\begin{array}{l}\text { Patients receiving } \\
\text { HCT and cellular } \\
\text { therapies. }\end{array}$ & $\begin{array}{l}\text { A review involving the clinical adaptation } \\
\text { of hematopoietic stem cell (HCT) transplant } \\
\text { services or cell therapy with the aid of the } \\
\text { Internet. }\end{array}$ & $\begin{array}{l}\text { Pharmacists working remotely in hospitals can virtually care for patients who have } \\
\text { had an HCT transplant. Applications such as MedActionPlan Pro®, which organize a } \\
\text { medication calendar, can be used. There are also several applications to establish good } \\
\text { communication with the medical team, they are: Skype for Business }{ }^{\circledR} \text {, Facetime }{ }^{\circledR} \text {, } \\
\text { Zoom }{ }^{\circledR} \text {, Epic } ® \text { chat, Jabber }{ }^{\circledR} \text {, Cureatr } ® \text { and Voalte } \AA \text {. }\end{array}$ \\
\hline $\begin{array}{l}\text { Zhang et al., } \\
2020 \text { (China). }\end{array}$ & $\begin{array}{l}\text { A multiple myeloma } \\
\text { patient with Covid- } 19 .\end{array}$ & $\begin{array}{l}\text { A case report of treatment with the } \\
\text { humanized anti-IL-6 receptor antibody } \\
\text { tocilizumab. }\end{array}$ & $\begin{array}{l}\text { Man, } 60 \text { years old wiht chest tightness and cough was hospitalized immediately after } \\
\text { the chest CT scan showed opacities and pneumatocele, positive for COVID-19. } \\
\text { Antibiotic }+ \text { antiviral for } 3 \text { days. History of MM with chemotherapy. Tests revealed } \\
\text { lymphocytopenia high levels of IL- } 6 \text {. The patient was given } 8 \mathrm{mg} / \mathrm{kg} \text { tocilizumab, } \\
\text { administered } 1 \text { time and the chest tightness disappeared and the IL-6 level decreased } \\
\text { from } 121.59 \text { to } 20.81 \mathrm{pg} / \mathrm{ml} \text {, and then returned to } 117.10 \mathrm{pg} / \mathrm{ml} \text {. This drop in IL- } 6 \\
\text { levels and, soon after, its increase can be attributed to the recovery of T cells. The } 3 \mathrm{rd} \\
\text { CT scan showed an improvement in the condition and the patient was declared cured. } \\
\text { With this case, the efficacy of using Tocilizumab in the treatment of Covid-19 in a } \\
\text { patient with MM was suggested and, in the future, randomized controlled trials are }\end{array}$ \\
\hline
\end{tabular}




\begin{tabular}{|c|c|c|c|}
\hline & & & needed. \\
\hline $\begin{array}{l}\text { Ardura et al., } \\
2020 \text { (EUA). }\end{array}$ & $\begin{array}{l}\text { Immunocompromised } \\
\text { patients, HCT donors } \\
\text { and } \quad \text { medical } \\
\text { caregivers. }\end{array}$ & $\begin{array}{l}\text { A review considering a holistic model of } \\
\text { care. }\end{array}$ & $\begin{array}{l}\text { Research suggests that aggressive cancer treatments should be postponed and the } \\
\text { frequency of hospital visits reduced. Delays in transplants involving non-malignant } \\
\text { tumors are recommended. There is a negative impact of COVID-19 on blood } \\
\text { donations and drug supply, a possible interruption in the availability of certain drugs } \\
\text { by the pharmaceutical industry is anticipated. }\end{array}$ \\
\hline $\begin{array}{l}\text { Jin et al., } 2020 \\
\text { (China). }\end{array}$ & $\begin{array}{l}\text { One patient with } \\
\text { chronic lymphocytic } \\
\text { leukaemia. }\end{array}$ & $\begin{array}{l}\text { A case report considering non-invasive } \\
\text { ventilation therapy and the treatment with } \\
\text { oral chlorambucil ( } 2 \mathrm{mg}) \text {, nebulized } \alpha \text { - } \\
\text { interferon }(5000000 \mathrm{IU}) \text {, intravenous human } \\
\text { immunoglobulin }(20 \mathrm{~g}), \text { and intravenous } \\
\text { methylprednisolone }(40 \mathrm{mg}) \text {. }\end{array}$ & $\begin{array}{l}\text { The result of the haematological exams in the chronic lymphocytic leukaemia patient } \\
\text { can disguise COVID-19 usual findings. It is safer to use CT imaging or similar } \\
\text { techniques to diagnose the COVID-19. Patients undergoing cancer treatments and } \\
\text { other immunosuppressive therapies may manifest longer SARS-CoV-2 virus } \\
\text { incubation period. }\end{array}$ \\
\hline $\begin{array}{l}\text { Bachanova et al., } \\
2020 \text { (EUA). }\end{array}$ & $\begin{array}{l}\text { Pediatric ALL and } \\
\text { DLBCL patients. }\end{array}$ & $\begin{array}{l}\text { A review with general recommendations } \\
\text { about the management of cellular therapy } \\
\text { administration and patients follow up in the } \\
\text { COVID-19 pandemic. }\end{array}$ & $\begin{array}{l}\text { Patients with ALL and DLBCL remain a group with medical needs not satisfied. CAR } \\
\text { T cell therapy might lead to a remissive status. Due to the actual uncertain scenario, } \\
\text { the use of CAR T cell therapy will demand additional deliberations about the risks and } \\
\text { benefits. However, if a patient requires the therapy and its gains overcome the risks, } \\
\text { treatment must be provided. }\end{array}$ \\
\hline $\begin{array}{l}\text { Ljungman et al., } \\
2020 \text { (Sweden, } \\
\text { Italy, Spain, } \\
\text { Poland, France, } \\
\text { Germany, the } \\
\text { Netherlands, UK } \\
\text { and Poland). }\end{array}$ & 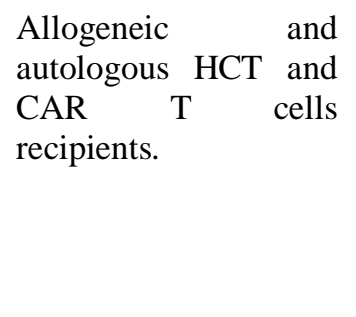 & $\begin{array}{l}\text { A review with guidelines for the proper } \\
\text { handling of transplant recipients and } \\
\text { candidates, beyond donor issues, in } \\
\text { transplant centers during the COVID-19 } \\
\text { pandemic. }\end{array}$ & $\begin{array}{l}\text { The COVID-19 pandemic outbreak set new defiances to the stem cell transplantation } \\
\text { process. Worldwide cooperation aiming to achieve enough information to avoid a } \\
\text { larger danger to patients that got through complex procedures such as HCT or cellular } \\
\text { therapy is necessary. Due to the divergences between public health and health care } \\
\text { statements in different contexts and places, the definition of specific measures } \\
\text { establishment by EBMT to be taken by the centers in an internal work level is not } \\
\text { viable. }\end{array}$ \\
\hline $\begin{array}{l}\text { Paul et al., } 2020 \\
\text { (USA). }\end{array}$ & Leukemia patients. & $\begin{array}{l}\text { A review with recommendations over the } \\
\text { optimization of leukemia management } \\
\text { during high-risk COVID- } 19 \text { periods. }\end{array}$ & $\begin{array}{l}\text { Screening for COVID-19, including a basic CT scan of the chest without contrast } \\
\text { should be done in all patients newly diagnosed with ALL and those receiving } \\
\text { consolidation therapy. Treatment with curative intent should be done in patients newly } \\
\text { diagnosed with ALL during the COVID-19 pandemic. One of the standard treatment } \\
\text { regimens for ALL is known as HCVAD. Therefore, treatment with four cycles of } \\
\text { mini-HCVD with inotuzumab and four cycles of blinatumomab, administered } \\
\text { sequentially, is recommended. For those over } 70 \text { years of age, the overall exposure to } \\
\text { cytotoxic chemotherapy is reduced, implementing an additional reduction to just two }\end{array}$ \\
\hline
\end{tabular}




\begin{tabular}{|l|l|l|}
\hline & $\mid \begin{array}{l}\text { cycles of mini-HCVD with inotuzumab, followed by eight cycles of blinatumomab. } \\
\text { During the COVID-19 pandemic, the general treatment of patients with recently } \\
\text { diagnosed with AML should not change. Patients undergoing induction chemotherapy } \\
\text { should be treated in a hospital environment, especially those aged over 50 years. The } \\
\text { initiation of new therapies in patients with chronic lymphocytic leukemia should be } \\
\text { postponed during the high-risk period of COVID-19, avoiding frequent visits to the } \\
\text { clinic and avoiding possible hospitalization. Patients with myelodysplasurstic } \\
\text { syndromes or myelodysplastic/myeloproliferative neoplasms should be considered at } \\
\text { high risk for COVID-19. Appropriate antibiotic prophylaxis should be received by } \\
\text { patients with acute leukemia, including antibacterial, antifungal and antiviral agents, } \\
\text { during periods of neutropenia. There are some ways to provide effective and safe } \\
\text { treatment such as using less intensive therapies, reducing patient visits and } \\
\text { establishing collaborative care in local centers or by telemedicine. The treatments } \\
\text { need to be decided individually, assessing factors related to the patient, risk of } \\
\text { additional toxicity from chemotherapy and the feasibility of administering the } \\
\text { treatment. }\end{array}$ \\
\hline
\end{tabular}

Abbreviations: HCT - hematopoietic stem cell; COVID-19 - coronavirus disease 2019; IL-6 - Interleukin 6; CT - computed tomography; MM - multiple myeloma; IV - Intravenous; IU - International unit; SARS-CoV-2 - severe acute respiratory syndrome coronavirus 2; ALL - acute lymphoblastic leukemia; DLBCL - Diffuse large B-cell lymphoma; CAR T - Chimeric antigen receptor T; EBMT - European Society for Blood and Marrow Transplantation; HCVD - low intensity chemotherapy; R/R - relapsed/refractory; AML - Acute Myeloid Leukemia.

Source: Authors (2021). 


\subsection{Clinical presentation, susceptibility and diagnosis for cancer patients}

Data on clinical presentation, susceptibility and diagnosis correlated in patients with cancer and COVID-19 are compiled in Table 1. Cancer patients are a group that deserves a special study in the midst of a pandemic. Studies show that these patients are susceptible to having poor prognosis if infected with COVID-19 (Ky \& Mann, 2020; Gosain, et al., 2020; Dariya \& Nagaraju, 2020). The most common complications include: the evolution of disease with greater speed, need for ICU / hospitalization, invasive ventilation and even death (Ky \& Mann, 2020; Gosain, et al., 2020; Dariya \& Nagaraju, 2020). Among the most common cancer types associate with SARS-CoV-2 infection are hematological malignancies, neutropenic or lymphopenic stand out compared with the heathy population of COVID-19 patients (Dariya \& Nagaraju, 2020). However, some studies suggest that the immunosuppressive condition does not suggest a risk for serious conditions if the patient is infected with SARS-CoV-2 (Minotti, et al., 2020; Spezzani, et al., 2020).

Cardiac damage is present in patients who are confirmed for COVID-19, representing a high risk (Dariya \& Nagaraju, 2020; Ky \& Mann, 2020), that can evolve to a critical condition and lead to death (Dariya, et al., 2020). Thus, cancer patients requiring rigorous evaluation on clinical examination, which are usually indicated, among other factors, by the high level of troponin I (Ky \& Mann, 2020). It is also noted that, in some cases, immunosuppressed patients (including cancer patients) infected with coronavirus may be asymptomatic (Albano, et al., 2020; Minotti, et al., 2020). The tests help in the diagnosis of patients infected with coronavirus and favored the choice of an effective treatment, taking into account the patient's age, affected organ and stage of the cancer, reducing the mortality rate (Dariya \& Nagaraju, 2020).

Nuclear medicine showed incidental findings suggestive of COVID-19 in some asymptomatic patients, when they underwent tests for other purposes (Albano, et al., 2020). Thus, policies are being formulated to find the best treatment plan or medical protocol to deal with cases of cancer patients who are affected by COVID-19, controlling infections in hospital environments (Minotti, et al., 2020; Gosain, et al., 2020; Dariya \& Nagaraju, 2020; Albano, et al., 2020). In view of the findings in the scientific literature, it is observed that measures such as postponement of cancer treatments and reprogramming of cancer surgery can potentially affect the survival of these patients (Albano, et al., 2020; Gosain, et al., 2020; Minotti, et al., 2020). However, treatments that can result in a change in the course of the disease (transplantation or chemotherapy) must be evaluated on the real need for postponement or discontinuation, and these changes in therapy are not indicated (Minotti, et al., 2020). In addition, it is important that the health professional is attentive to the presence of these patients in a hospital environment, reducing, when possible, their presence in that location, mitigating the possibility of possible contamination by SARS-CoV-2 and / or other diseases (Gosain, et al., 2020; Minotti, et al., 2020).

There is no distinction in the use of COVID-19 drug therapy for cancer patients compared with the rest of the population or with other immunocompromised patients (Gosain, et al., 2020). The use of immunomodulatory drugs (such as tocilizumab, sarilumab and emapalumab) are used in cancer patients who are undergoing immunotherapy, showing good results for the "cytokine storm", however studies in patients with COVID-19 are ongoing (Ciliberto, et al., 2020). On the other hand, Dariya \& Nagaraju (2020) indicate that patients with cancer and COVID-19 should avoid using immunosuppressive drugs or administer low doses (Dariya \& Nagaraju, 2020). Another study demonstrated that the use of tocilizumab improved clinical outcomes in patients with COVID-19, attenuating lung damage in severe cases (Gosain, et al., 2020). The evaluation of the efficacy of Janus-associated kinase (JAK) inhibiting agents is underway aiming to analyze their anti-inflammatory effects in patients with COVID-19, also evaluating whether baricitinib can interrupt the entry of the virus in cells since can act an inhibitor of AP2-associated protein kinase 1 (AAK1) (Gosain, et al., 2020). 


\subsection{General Management of cancer patients}

The table 2 present the publications that focused on the general management of cancer patients at the reality faced. Were seen that, due to the possible implications of COVID-19 for the group of cancer patients, numerous oncology centers sought to adapt to the pandemic with a primary focus on ensuring the protection of patients and professionals against the possibility of infection, without compromising the provision of quality care. There were changes in therapeutic schemes, in the flow of shifts, in the cleaning and disinfection processes, among many others.

The approach, management, and guarantee of appropriate care for cancer patients have always been a delicate issue since it tends to involve numerous variables. The emergence of a pandemic made this task even harder. The uncertainty regarding SARS-CoV-2 infection and its implications in oncologic patients represents an additional stressor. Despite current scenario, seems crucial to maintaining treatment and follow-up, especially for patients with great curative possibilities or in severe stages of the disease (von Lilienfeld-Toal, et al., 2020) since in the long-term cancer may represent a much substantial risk to the lives of patients than SARS-CoV-2 infection itself (Moujaess, et al., 2020). Thus, since the beginning of the pandemic, cancer centers face the need to continue adapting to guarantee a better result in the face of the unfavorable situation currently faced (Weisel, et al., 2020).

Some major societies and entities in oncology have developed guidelines for the management of some types of cancer. However, there is no universal consensus on what would be the best measures to maintain the quality of care provided by the services and, still, to avoid the spread of the COVID-19 between patients and staff. Thus, the decisions taken should be based on scientific evidence, on the opinion of managers and local authorities, on the experience of professionals, on the availability of material and human resources, in addition to the individual analysis of each patient's condition (Combs, et al., 2020). Professionals should encourage patients to improve health care themselves, searching for a healthy diet, leaving harmful addictions/habits, and increasing the practice of physical activities (von Lilienfeld-Toal, et al., 2020). Furthermore, health care teams must also enhance the psychological support offered to them (Nannan, et al., 2020). The issues involved in the course of cancer already generates anxiety. Also, patients must deal with doubts about SARS-CoV-2 infection and its unfavorable evolution among cancer patients besides the fear of having their treatment and follow-up compromised due to lack of resources (van de Haar, et al., 2020; Weisel, et al., 2020).

In several services, some initiatives appear to be usual: such as the search for more assertive measures of hygiene and disinfection of materials and environments, that sometimes are divided into different risk zones; the incentive to comply with distance measures and to use of protective equipment by professionals and patients; as well as the promotion of proper education and training to the staff considering SARS-CoV-2 infection particularities (Nannan, et al., 2020; Combs, et al., 2020; Wei, et al., 2020). Some services are also promoting a frequent turnover among employees (Wei, et al., 2020); or dividing them into small teams with shorter, alternating shifts (Ierardi, et al., 2020) to reduce the dissemination of the virus and maintain the staff resource. There seems to be a divergence about the presence of companions during treatment and visits to oncology services. Some places have allowed their presence, as long as it meets the necessary measures, as undergoing testing and some exams (Wei, et al., 2020). But most have summarily limited/forbidden the presence of companions during visits or visits to hospitalized patients (van de Haar, et al., 2020; Weisel, et al., 2020; Combs, et al,.2020).

The diagnosis of SARS-CoV-2 infection in oncologic patients turns out to be also a complicating factor in the process. These patients can present findings that mask possible affections: such as findings in imaging tests without any relation to the infection; they also can show nonspecific symptoms and varied laboratory alterations related to the pre-existing condition, misleading the diagnosis (Moujaess, et al., 2020). For this reason, constant and thorough observation and examination of patients (Nannan, et al., 2020) become necessary to avoid substantial problems and allow early detection to define what are the best options for the patient. Cancer treatments may interfere in the immune response and the functioning of 
the organism. This fact could hinder the evolution of SARS-CoV-2 infection. For that matter, some teams are choosing to completely stop the treatment of those who are infected until there is the resolution of the condition (von Lilienfeld-Toal, et al., 2020; Wei, et al., 2020; Combs, et al., 2020). Meanwhile, others have been opted to continue with treatment but only through adequate isolation, even when the patient presents suggestive symptoms (Ierardi, et al., 2020).

Numerous types of cancer have a considerable response to radiotherapy. This type of therapy functions also as an adjuvant alternative in many cases (Combs, et al., 2020; Wei, et al., 2020). In this pandemic period, despite the reduction in the number of surgical interventions in this group of patients (Nannan, et al., 2020; van de Haar, et al., 2020), radiotherapy is one of the temporary options. Most of the reports in the literature revolve around adaptations and protocols adopted favoring the proper functioning of this sector. The concern regarding the possibility to continue with the research and clinical trials already underway is also a subject given their future importance for ensuring a better prognosis for patients (Weisel, et al., 2020). Some groups have turned their resources towards research aimed at combating COVID-19. But a few, based on the guidelines established by the FDA (Food and Drug Administration) and other authorities, are continuing the activities by adopting the proposed changes to protocols (Moujaess, et al., 2020). The measures sanctioned by oncology centers appear to be successful, favoring the treatment and monitoring of patients. Nevertheless, one of the significant impacts of the pandemic will only materialize in the future. As there will be a long delay in the diagnosis of new cases, patients will tend to have more advanced stages of the disease (Weisel, et al., 2020).

\subsection{Surgical procedures in Oncology during outbreak}

Table 3 presents an overview of publications about cancer surgeries, in order to orient in which situations these must or will not be adhered to. The initiation of new treatments is being contraindicated in case of infection by SARS-CoV-2. In addition, it is suggested to reconsider and possibly replace therapeutic strategies in view of the imposed limitations, with the surgical approach often being postponed in cases evaluated less urgently by established guidelines - there are caveats regarding this practice due to the chance of a worse prognosis for the patient.

It has been noticed that patients diagnosed with cancer and SARS-CoV-2 infection show an increase in complication rate, admission to intensive care units, need for ventilatory support, poor overall prognosis and death (Shinde, et al., 2020). Based on this major concern, surgeons who treat cancer are confronted by complicated ethical and moral dilemmas because most cancer surgeries are elective but, sometimes, cannot be postponed due to the evolution of the disease and the chances of survival (Deo, et al., 2020).

Regarding this possible postponement of surgical procedures, in view of a possible overload of health services towards the COVID-19 pandemic, as well as the scarcity of potential resources, it has been recommended that, in order to make a decision, each case be analyzed individually (Shinde, et al., 2020; Deo, et al., 2020; Puliatti, et al., 2020; Glehen, et al., 2020). On the one hand, there is a risk of greater postoperative morbidity and mortality due to delayed surgery and possible disease progression (Shinde, et al., 2020); on the other, there is a concern about the risk of increased infection, which is related to the immunocompromised patient status and to the anticancer treatments (Puliatti, et al., 2020). In addition, some medical areas, such as neuro-oncology, are substantially affected by resource constraints, and, thereby, have a direct impact on survival. Besides that, as an effect of replacing face-to-face consultations for teleconsultations, the assessment of these patients' cognitive functions is also harmed (Weller \& Preusser, 2020).

Despite the possibility of postponing surgery for some types of tumor with their specifics staging (such as for prostate cancer and most kidney cancers), it is worth noting that some measures may contribute to minimize contamination rates such as cleaning surfaces and equipment during and between surgical procedures, regular changing of gloves, regular hand washing, intubation assisted by videolaryngoscopy whenever possible and adequate hygiene and disinfection procedures (Shinde, et al., 
2020). Another option for this scenario, in case for laparoscopic surgery, would be the Robot assisted surgery (RAS), a technique capable to reduce the contamination by body fluids and which requires a reduced number of medical staffs, fundamental specially at the current situation (Kimmig, et al., 2020).

In a case report made by Ye et al (2020), the authors described a case of a patient infected with SARS-CoV-2, whose medical conduct was to wait the tests to turn negative to make the resection. Besides the promising result, more consistent evidence is necessary to further apply this approach. This specific care is valid once Huang et al. (2020) described the presence of COVID-19 RNA in human fecal matter. In this way, all the operative tissue and refuse removed in the bowel surgeries will probably contain fecal contamination. In sum, based on the evidence of SARS-CoV-2 in human fecal matter and its survival allowing fecal-oral transmission, it is suggested that SARS-CoV-2 may also present this means of transmission (Yeo, et al., 2020). Tchelebi et al. (2020), through a review, list several suggestions related to medical practices for patients with gastrointestinal tumors, emphasizing radiotherapy and based on the RADS principle (remote visits, avoid radiation, postpone radiation, reduce radiation).

Therefore, the decision to postpone or not the oncological surgeries must be made in a multidisciplinary and individualized way, considering both the patient's and family's wishes, guiding them as to the risks and benefits, providing a conscious decision (Puliatti, et al., 2020; Weller \& Preusser, 2020).

\subsection{Management of lung cancer and haemathological tumors}

As previously mentioned, the management of lung cancer cases is being subjected to careful and specific assessments for each condition. In the case of hematological tumors, these patients are more susceptible to contamination by the new SARS-CoV-2 with a longer incubation period, due to their lower immunocompetence and generally associated with a worse prognosis. These two tumor types were, separately, frequently mentioned in the works selected in the methodology applied for this review. There is a clear concern / interest in changes in clinical management for these two tumor types. In this sense, the table 4 presents a compilation of information about concerns and appropriate clinical management for patients with lung cancer, while the table 5 presents a review of clinical management focused on patients with hematological tumors and those infected with SARS-CoV-2.

Treatment approaches for patients with lung cancer have been significantly impacted by the current pandemic and decisions about the treatment were submitted to new questions and guidelines. For patients with lung cancer in general, it is recommended that all of them who have had contact with people tested positive for SARS-CoV-2 should also be tested before starting any treatment. With the result, the team must carefully analyze the risks and benefits of the possible conducts in order to indicate the one that brings the greatest benefits to the patient, and, if the patient is infected, it is indicated not to start a treatment until 28 days after the positive test and only with two negative interval tests. one week, that is, the treatment of the tumor can be postponed in this scenario (Banna, et al., 2020).

The papers deal with the need to consider treatment alternatives for lung cancer in view of the limitations imposed by the crisis in the pandemic. For example, among the countless patients waiting for surgeries in queues, not all will be able to be seen in the planned time due to the closure of several operating rooms and the unavailability of beds, vestments and even professionals, which implies their relocation based on urgency order and guidelines; in addition, alternative therapies such as chemotherapy, radiotherapy, immunosuppression, can be considered, although the work concludes that it is more recommended not to replace surgical therapy, when indicated, with treatments that cause immunosuppression under the penalty of poor prognosis for the patient (de la Viña, et al., 2020).

In general, there is considerable concern about the negative effects of this crisis on the management of lung cancer, a serious disease whose treatment is usually indispensable for the patient's survival, in addition to being mainly associated with 
surgical practice, one of the areas most affected by preventive measures and coping with COVID-19 in hospitals (Banna, et al., 2020; de la Viña, et al., 2020; Zhang, et al., 2020a; 2020b; 2020c).

Patients with hematological diseases, patients undergoing treatment for leukemia (Jin, 2020) and patients who are treated with hematopoietic stem cell transplantation (HSCT) (Mahmoudjafari, et al., 2020) are a preocupation because can be more easily infected (Ardura, et al., 2020) may experience a longer incubation period for SARS-CoV-2 viruses (Jin, et al., 2020) due to the treatment. COVID-19 also has a negative impact on blood donations and the availability of medicines, aggravating a patient's situation.

For better coping and safe medical care, in the face of the new reality, reduction in visits is advisable in the frequency of hospital visits (Ardura, et al.,2020) and restructure hospital teams, clinical management and service provider for patients receiving HCT therapies (Mahmoudjafari, et al., 2020), as well as choosing less intensive therapies that also cause fewer hospitalizations and refer patients to collaborative assistants in centers local or telemedicine. This set of actions deals with effective and safe treatment for patients (Paul, et al., 2020).

\section{Conclusion}

This systematic review reinforces the need for cancer treatment centers to take measures to prevent the spread of COVID-19 in their facilities, in order to keep their activities going. Considering that cancer patients can evolve with a worse course of infection and the exposure of professionals would, ultimately, reduce the workforce and increase the vulnerability of cancer patients. Professionals involved in cancer care must reflect on the approaches individually, observing both the ethical aspects and the issues related to the type and staging of the tumors as well as the procedures and treatments proposed in times of SARS-CoV-2 pandemic. In the light of a multifaceted and challenging context, the decision to postpone or cancel antineoplastic treatments should prioritize quality of life and patient safety, in addition to considering the availability of medical and hospital resources during the COVID-19 pandemic.

During this systematic review elaboration and considering the pandemic situation that remains in effect worldwide, we observed that the work on cancer and COVID-19 are and should prevail on the rise. In this sense, as the implications of coronavirus infection in the medium and long term, especially in cancer patients, are not yet fully known at all by health professionals and the scientific community, it is notable that research on the subject continues to evolve. Therefore, we believe that there should be no lack of effort because much information and findings are yet to come. It is also relevant to develop more specific research about each type of cancer, its implications, and management during pandemics, fostering the research already carried out and providing new directions.

\section{Acknowledgments}

We thank and dedicate this work to our colleague Bethânia Cristina Vieira (in memoriam) for all the effort, affection, and companionship. We are grateful for the moments lived and all the lessons learned in our relationship as a team. We also thank the Federal University of Alfenas for supporting students and encouraging them to carry out this work.

\section{References}

Ackermann, M., Verleden, S. E., Kuehnel, M., Haverich, A., Welte, T., Laenger, F., Vanstapel, A., Werlein, C., Stark, H., Tzankov, A., Li, W. W., Li, V. W., Mentzer, S. J. \& Jonigk, D. (2020). Pulmonary vascular endothelialitis, thrombosis, and angiogenesis in Covid-19. New England Journal of Medicine. 10.1056/NEJMoa2015432.

Al-Shamsi, H. O., Alhazzani, W., Alhuraiji, A., Coomes, E. A., Chemaly, R. F., Almuhanna, M., Wolff, R. A., Ibrahim, N.K., Chua, M. L. K., Hotte, S. J., Meyers, B. M., Elfiki, T., Curigliano, G., Eng, C., Grothey, A. \& Xie, C. (2020). A practical approach to the management of cancer patients during the novel coronavirus disease 2019 (COVID-19) pandemic: an international collaborative group. The oncologist, 25(6), e936. 10.1634/theoncologist.2020-0213. 
Albano, D., Bertagna, F., Bertoli, M., Bosio, G., Lucchini, S., Motta, F., Panarotto, M. B., Peli, A., Camoni, L., Bengel, F. M. \& Giubbini, R. (2020). Incidental findings suggestive of COVID-19 in asymptomatic patients undergoing nuclear medicine procedures in a high-prevalence region. Journal of Nuclear Medicine, 61(5), 632-636. 10.2967/jnumed.120.246256.

Ardura, M., Hartley, D., Dandoy, C., Lehmann, L., Jaglowski, S., \& Auletta, J. J. (2020). Addressing the impact of the Coronavirus Disease (COVID-19) pandemic on hematopoietic cell transplantation: Learning networks as means for sharing best practices. Biology of Blood and Marrow Transplantation. 10.1016/j.bbmt.2020.04.018.

Bachanova, V., Bishop, M. R., Dahi, P., Dholaria, B., Grupp, S. A., Hayes-Lattin, B., Janakiram, M., Maziarz, R. T., McGuirk, J. P., Nastoupil, L. J., Oluwole, O. O., Perales, M-A., Porter, D. L. \& Riedell, P. A. (2020). CAR T Cell Therapy During the COVID-19 Pandemic. Biology of Blood and Marrow Transplantation. 10.1016/j.bbmt.2020.04.008.

Banna, G., Curioni-Fontecedro, A., Friedlaender, A., \& Addeo, A. (2020). How we treat patients with lung cancer during the SARS-CoV-2 pandemic: primum non nocere. ESMO open, 4(Supp1 2), e000765. DOI:10.1136/ esmoopen-2020-000765.

Ciliberto, G., Mancini, R., \& Paggi, M. G. (2020). Drug repurposing against COVID-19: focus on anticancer agents. Journal of Experimental \& Clinical Cancer Research, 39, 1-9. 10.1186/s13046-020-01590-2.

Combs, S. E., Belka, C., Niyazi, M., Corradini, S., Pigorsch, S., Wilkens, J., Grosu, A. L., Guckenberger, M., Ganswindt, U. \& Bernhardt, D. (2020). First statement on preparation for the COVID-19 pandemic in large German Speaking University-based radiation oncology departments. Radiation Oncology, 15, 1-12. 10.1186/s13014-020-01527-1.

Cucinotta, D., \& Vanelli, M. (2020). WHO declares COVID-19 a pandemic. Acta bio-medica: Atenei Parmensis, 91(1), 157-160. 10.23750/abm.v91i1.9397.

Dariya, B., \& Nagaraju, G. P. (2020). Understanding novel COVID-19: Its impact on organ failure and risk assessment for diabetic and cancer patients. Cytokine \& Growth Factor Reviews. 10.1016/j.cytogfr.2020.05.001.

de la Viña, J. I., \& Mayol, J., \& Ortega, A. L., \& Navarrete, B. A. (2020). Lung cancer patients on the waiting list in the midst of the COVID-19 crisis: what do we do now? Archivos de bronconeumologia. 10.1016/j.arbr.2020.05.003.

Deo, S., Kumar, S., Kumar, N., Saikia, J., Bhoriwal, S., Bhatnagar, S., \& Sharma, A. (2020). Guiding Principles for Cancer Surgery during the COVID-19 Pandemic. Indian Journal of Surgical Oncology, 1. 10.1007/s13193-020-01082-x.

Silva Filho, P. S. Da P.; Costa, R. E. A. R. Da; Santos, M. B. L. Dos; Lima, S. P. N.; Silva, L. De A. Da; Freitas, A. S.; Silva, J. P. Da; Araújo, L. K. C. De; Cunha, S. H.; Araújo, F. W. C.; Silva, A. P. A. a; Alves, D. R. C. F.; Mendes, A. M.; Leão, C. De A.; Kirchesch, C. L.; Maced o, J. L. (2020). Management of patients with cancer during the COVID-19 pandemic. Research, Society and Development, 9 (7), p. e628974609, 2020. 10.33448/rsd-v9i7.4609.

Gandhi, R. T., Lynch, J. B., \& del Rio, C. (2020). Mild or moderate COVID-19. New England Journal of Medicine. 10.1056/NEJMcp2009249.

Glehen, O., Kepenekian, V., Bouché, O., Gladieff, L., \& Honore, C. (2020). Treatment of primary and metastatic peritoneal tumors in the Covid-19 pandemic. Journal of Visceral Surgery. 10.1016/j.jviscsurg.2020.04.013.

Gosain, R., Abdou, Y., Singh, A., Rana, N., Puzanov, I., \& Ernstoff, M. S. (2020). COVID-19 and cancer: a comprehensive review. Current Oncology Reports, 22(5). 10.1007/s11912-020-00934-7.

Guo, Y.-R., Cao, Q.-D., Hong, Z.-S., Tan, Y.-Y., Chen, S.-D., Jin, H.-J., Tan, K-S., Wang, D-Y. \& Yan, Y. (2020). The origin, transmission and clinical therapies on coronavirus disease 2019 (COVID-19) outbreak-an update on the status. Military Medical Research, 7(1), 1-10. 10.1186/s40779-020-00240-0.

Huang, Z., Yan, J., Jin, T., Huang, X., Zeng, G., Adashek, M. L., Wang, X., Li, J., Zhou, D. \& Wu, Z. (2020). The Challenges Of Urgent Radical Sigmoid Colorectal Cancer Resection In A COVID-19 Patient; A Case Report. International Journal of Surgery Case Reports. 10.1016/j.ijscr.2020.04.088.

Ierardi, A. M., Wood, B. J., Gaudino, C., Angileri, S. A., Jones, E. C., Hausegger, K., \& Carrafiello, G. (2020). How to Handle a COVID-19 Patient in the Angiographic Suite. Cardiovascular and Interventional Radiology, 1-7. 10.1007/s00270-020-02476-8.

Jin, X.-H., Zheng, K. I., Pan, K.-H., Xie, Y.P., \& Zheng, M.-H. (2020). COVID-19 in a patient with chronic lymphocytic leukaemia. The Lancet Haematology, 7(4), e351-e352. 10.1016/S2352-3026(20)30074-0.

Kimmig, R., Verheijen, R. H., \& Rudnicki, M. (2020). Robot assisted surgery during the COVID-19 pandemic, especially for gynecological cancer: a statement of the Society of European Robotic Gynaecological Surgery (SERGS). Journal of Gynecologic Oncology, 31(3). 10.3802/jgo.2020.31.e59.

Ky, B., \& Mann, D. L. (2020). COVID-19 Clinical Trials: A Primer for the Cardiovascular and Cardio-Oncology Communities. JACC: Basic to Translational Science, 5(5), 501-517. 10.1016/j.jacbts.2020.04.003.

Ljungman, P., Mikulska, M., de la Camara, R., Basak, G. W., Chabannon, C., Corbacioglu, S., Duarte, R., Dolstra, H., Lankester, A. C., Mohty, M., Montoto, S., Murray, J., de Latour, R. P., Snowden, J. A., Yakoub-Agha, I., Verhoeven, B., Kröger, N. \& Styczynski, J. (2020). The challenge of COVID-19 and hematopoietic cell transplantation; EBMT recommendations for management of hematopoietic cell transplant recipients, their donors, and patients undergoing CAR T-cell therapy. Bone marrow transplantation, 1-6. 10.1038/s41409-020-0919-0.

Mahmoudjafari, Z., Alexander, M., Roddy, J., Shaw, R., Shigle, T. L., Timlin, C., \& Culos, K. (2020). American Society for Transplantation and Cellular Therapy Pharmacy Special Interest Group Position Statement on Pharmacy Practice Management and Clinical Management for COVID-19 in Hematopoietic Cell Transplant and Cellular Therapy Patients in the United States. Biology of Blood and Marrow Transplantation. 10.1016/j.bbmt.2020.04.005.

Minotti, C., Tirelli, F., Barbieri, E., Giaquinto, C., \& Donà, D. (2020). How is immunosuppressive status affecting children and adults in SARS-CoV-2 infection? A systematic review. Journal of Infection. 10.1016/j.jinf.2020.04.026. 
Moher, D., Shamseer, L., Clarke, M., Ghersi, D., Liberati, A., Petticrew, M., Shekelle, P. \& Stewart, L. A. (2015). Preferred reporting items for systematic review and meta-analysis protocols (PRISMA-P) 2015 statement. Systematic reviews, 4(1), 1. 10.1186/2046-4053-4-1.

Moujaess, E., Kourie, H. R., \& Ghosn, M. (2020). Cancer patients and research during COVID-19 pandemic: a systematic review of current evidence. Critical Reviews in Oncology/Hematology, 102972. 10.1016/j.critrevonc.2020.102972.

Nannan, Z., Jie, S., Lizhong, Z., \& Shuanying, Y. (2020). Clinical Characteristics and Coping Strategies of Neoplasms with 2019 Novel Coronavirus Infection. Chinese Journal of Lung Cancer, 23(4). 10.3779/j.issn.1009-3419.2020.102.15.

Paul, S., Rausch, C. R., Jain, N., Kadia, T., Ravandi, F., DiNardo, C. D., Welch, M. A., Dabaja, B. S., Daver, N., Garcia-Manero, G., Wierda, W., Pemmaraju, N., Bravo, G. M., Thompson, P., Verstovsek, S., Konopleva, M., Kantarjian, H. \& Jabbour, E. (2020). Treating Leukemia in the Time of COVID-19. Acta Haematologica, 1-13. 10.1159/000508199.

Pawar, T., Pokharkar, A., Gori, J., Pandey, D., Rohila, J., Dsouza, A., \& Saklani, A. (2020). The Technique and Justification for Minimally Invasive Surgery in COVID-19 Pandemic: Laparoscopic Anterior Resection for Near Obstructed Rectal Carcinoma. Journal of Laparoendoscopic \& Advanced Surgical Techniques, 30(5), 485-487. 10.1089/lap.2020.0241.

Pimentel, B. (2020). As disfunções olfativas e gustativas como apresentação clínica da COVID-19. Research, Society and Development, 9 (8), e64985072. http://dx.doi.org/10.33448/rsd-v9i8.5072.

Pereira, A. S., Shitsuka, D. M., Parreira, F. J., \& Shitsuka, R. (2018). Metodologia da Pesquisa Científica. UFSM. https://repositorio.ufsm.br/bitstream/handle/1/15824/Lic_Computacao_Metodologia-Pesquisa -Cientifica.pdf?sequence=1.

Puliatti, S., Eissa, A., Eissa, R., Amato, M., Mazzone, E., Dell’Oglio, P., Sighinolfi, M. C., Zoeir, A., Micali, S., Bianchi, G., Patel, V., Wiklund, P., Coelho, R. F., Bernhard, J-C., Dasgupta, P., Mottrie, A. \& Rocco, B. (2020). COVID-19 and urology: A comprehensive review of the literature. BJU international. $10.1111 /$ bju.15071.

Shinde, R. S., Naik, M. D., Shinde, S. R., Bhandare, M. S., Chaudhari, V. A., Shrikhande, S. V., \& Dcruz, A. K. (2020). To Do or Not to Do?-A Review of Cancer Surgery Triage Guidelines in COVID-19 Pandemic. Indian Journal of Surgical Oncology, 1. 10.1007/s13193-020-01086-7.

Spezzani, V., Piunno, A., \& Iselin, H.-U. (2020). Benign COVID-19 in an immunocompromised cancer patient-the case of a married couple. Swiss Medical Weekly, 150(1516). 10.4414/smw.2020.20246.

Tchelebi, L. T., Haustermans, K., Scorsetti, M., Hosni, A., Huguet, F., Hawkins, M. A., Dawson, L. A. \& Goodman, K. A. (2020). Recommendations on the use of radiation therapy in managing patients with gastrointestinal malignancies in the era of COVID-19. Radiotherapy and Oncology. 10.1016/j.radonc.2020.04.010.

Tian, S., Hu, W., Niu, L., Liu, H., Xu, H., \& Xiao, S.-Y. (2020). Pulmonary pathology of early phase 2019 novel coronavirus (COVID-19) pneumonia in two patients with lung cancer. Journal of Thoracic Oncology. 10.1016/j.jtho.2020.02.010.

van de Haar, J., Hoes, L. R., Coles, C. E., Seamon, K., Fröhling, S., Jäger, D., Valenza, F., de Braud, F., de Petris, L., Bergh, J., Ernberg, I., Besse, B., Barlesi, F., Garralda, E., Piris-Giménez, A., Baumann, M., Apolone, G., Soria, J. C., Tabernero, J., Caldas, C. \& Voest, E. E. (2020). Caring for patients with cancer in the COVID-19 era. Nature Medicine, 26(5), 665-671. 10.1038/s41591-020-0874-8.

von Lilienfeld-Toal, M., Vehreschild, J. J., Cornely, O., Pagano, L., Compagno, F., \& Hirsch, H. H. (2020). Frequently asked questions regarding SARS-CoV2 in cancer patients - recommendations for clinicians caring for patients with malignant diseases. Leukemia, 1-8. 10.1038/s41375-020-0832-y.

Wei, W., Zheng, D., Lei, Y., Wu, S., Verma, V., Liu, Y., Wei, X., Bi, J., Hu, D. \& Han, G. (2020). Radiotherapy workflow and protection procedures during the Coronavirus Disease 2019 (COVID-19) outbreak: Experience of the Hubei Cancer Hospital in Wuhan, China. Radiotherapy and Oncology. 10.1016/j.radonc.2020.03.029.

Weisel, K. C., Morgner-Miehlke, A., Petersen, C., Fiedler, W., Block, A., Schafhausen, P., Knobloch, J. K. \& Bokemeyer, C. (2020). Implications of SARSCoV-2 Infection and COVID-19 Crisis on Clinical Cancer Care: Report of the University Cancer Center Hamburg. Oncology Research and Treatment, 43(6), 307-313. 10.1159/000508272.

Weller, M., \& Preusser, M. (2020). How we treat patients with brain tumour during the COVID-19 pandemic. ESMO open, 4(Suppl 2), e000789. 10.1136/esmoopen-2020-000789.

World Health Organization (2020). Rolling updates on coronavirus disease (COVID-19). Retrieved from: https://www.who.int/emergencies/diseases/novelcoronavirus-2019/events-as-they-happen.

Ye, Z., Hong, Y., Wu, X., Hong, D., Zhang, Y., Dong, X., Rao, Y. \& Lu, X. (2020). Management of a colon cancer patient infected with corona virus disease 2019. Journal of Zhejiang University (Medical Science), 49(1), 0-0. 10.3785/j.issn.1008-9292.2020.03.12.

Yeo, C., Kaushal, S., \& Yeo, D. (2020). Enteric involvement of coronaviruses: is faecal-oral transmission of SARS-CoV-2 possible? The lancet Gastroenterology \& hepatology, 5(4), 335-337. 10.1016/S2468-1253(20)30048-0.

Zhang, H., Xie, C., \& Huang, Y. (2020c). Treatment and outcome of a patient with lung cancer infected with severe acute respiratory syndrome Coronavirus2. Journal of Thoracic Oncology, 15(5), e63-e64. 10.1016/j.jtho.2020.02.025.

Zhang, L., Zhu, F., Xie, L., Wang, C., Wang, J., Chen, R., Jia, P., Guan, H. Q., Peng, L., Chen, Y., Peng, P., Zhang, P., Chu, Q., Shen, Q., Wang, Y., Xu, S.Y., Zhao, P. J., \& Zhou, M. (2020a). Clinical characteristics of COVID-19-infected cancer patients: a retrospective case study in three hospitals within Wuhan, China. Annals of Oncology. 10.1016/j.annonc.2020.03.296. 
Research, Society and Development, v. 10, n. 3, e25910313251, 2021

(CC BY 4.0) | ISSN 2525-3409 | http://dx.doi.org/10.33448/rsd-v10i3.13251

Zhang, X., Song, K., Tong, F., Fei, M., Fei, M., Guo, H., Lu, Z., Wang, J., \& Zheng, C. (2020b). First case of COVID-19 in a patient with multiple myeloma successfully treated with tocilizumab. Blood advances, 4(7), 1307. 10.1182/bloodadvances.2020001907. 